\title{
VELOCITY MODELS INFERRED FROM P-WAVES TRAVEL TIME CURVES IN SOUTH AEGEAN
}

\section{Nikolintaga I. ${ }^{1,2}$, Karakostas V. ${ }^{1}$, Papadimitriou E. ${ }^{1}$, Vallianatos F. ${ }^{2}$, and Panopoulou G. ${ }^{3}$}

\author{
${ }^{I}$ Geophysics Department, School of Geology, Aristotle University of Thessaloniki, GR541124 \\ Thessaloniki,Greece,inikolin@geo.auth.gr,vkarak@geo.auth.gr,ritsa@geo.auth.gr \\ ${ }^{2}$ Technological Educational Institute of Crete, Department of Natural Resources \& Environment, \\ Geophysics \& Seismology Laboratory, fvallian@chania.teicrete.gr \\ ${ }^{3}$ Institute of Geodynamics, National Observatory of Athens, Greece,gpanop@gein.noa.gr
}

\begin{abstract}
The seismicity recorded during $1^{\text {st }}$ January to $31^{\text {st }}$ August 2005 from a new telemetry network installed and operating on the island of Crete, is used in an effort to obtain new velocity models for the area of south Aegean. The models are constructed from the $P$-waves travel time curves and are later used for the events relocation with the HYPOINVERSE algorithm and station delays calculation. Furthermore, results are discussed and compared with the ones derived from other significant previous works presented the last years. We anticipate by combining all the available information from the literature and the analysis of our data set to contribute to the seismotectonic modeling of the study area and to construct a most complete image of the geometry of the subducted plate.
\end{abstract}

Key words: velocity structure, earthquakes, relocation.

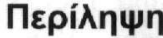

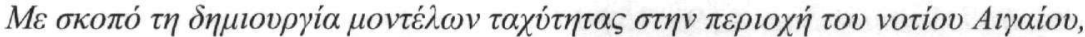

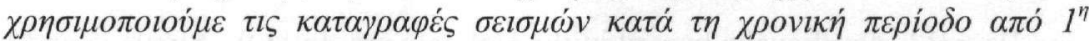

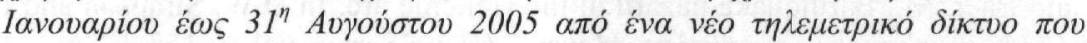

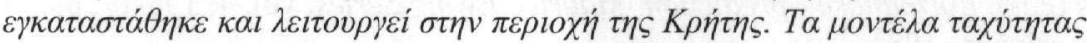

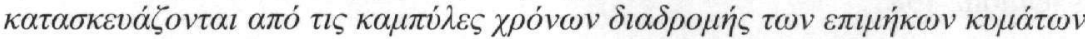

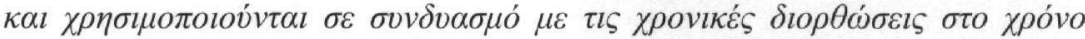

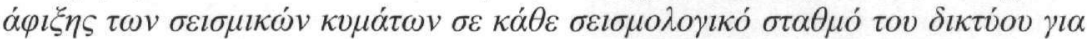

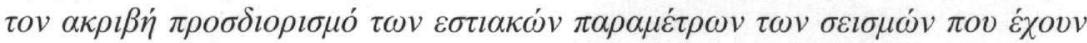

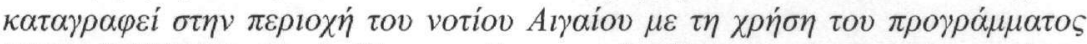

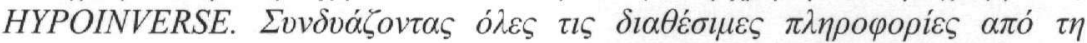

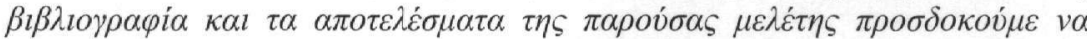

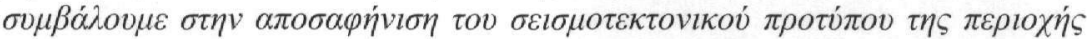

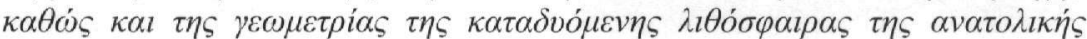

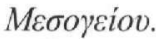

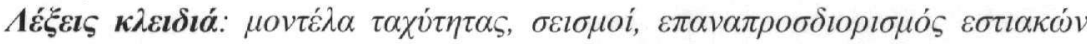
$\pi \alpha \rho \alpha \mu \dot{\tau} \rho \omega v$. 


\section{Introduction}

Over the past four decades, Aegean and its surroundings have attracted the interest of the scientific community worldwide since it is one of the most seismically active and one of the most rapidly deforming parts of the Alpine-Himalayan mountain belt. Its most prominent tectonic feature is the subduction of the eastern Mediterranean lithosphere under the Aegean Sea (Papazachos and Comninakis 1970) along the Hellenic Arc. The Aegean Sea is bounded to the north by the stable continental Eurasia, to the south by the African plate, to the east by the Anatolian microplate and to the west by the Adriatic microplate. The convergence between Eurasia and Africa is emerged due to the different rate of sea-floor spreading between the southern and northern part of the Atlantic Ocean, though the tectonics of the back-arc Aegean region is dominated by strike-slip and extensional motions. Even though the northward movement of the African plate is of about $1 \mathrm{~cm} / \mathrm{y}$, the convergence across the Hellenic Trench is approximately equal to $4.5 \mathrm{~cm} / \mathrm{y}$. This high rate is due both to the westward motion of Anatolia relative to Africa and to the rapid internal deformation of the Aegean (McKenzie 1988, Jackson 1994, Papazachos and Kiratzi 1996 among others) that affects the region itself.

Fundamental goal of numerous intensive studies has been the determination of the extremely complex plate dynamics in the broader Aegean area. The determination of focal mechanisms (e.g. Jackson and McKenzie 1988, Hatzfeld et al. 1989, Papazachos et al. 1991, Papazachos and Kiratzi 1996, Taymaz et al. 1990, Bohnhoff et al. 2005), and tectonic observations for the Miocene and the Quaternary time (Mercier et al. 1987, Armijo et al. 1996) have shown that along the Hellenic Arc thrust faulting prevails with P-axes trending roughly NE-SW, which is consistent with the underthrusting of the eastern Mediterranean oceanic lithosphere beneath Aegean. The complicated stress field is attributed to the westward motion of north Anatolia, to external compressional forces, exerted by the eastern Mediterranean and Apulian lithospheres and to intense internal deformation of the Aegean microplate.

Active reflection and refraction experiments yielded high resolution images of the top $20 \mathrm{~km}$ of the crust, while detailed tomographic studies provided information on the structure of the mantle (Spakman et al. 1993) and the velocity distribution in the crust (Papazachos et al. 1997). All this information is enhanced by magnetic and gravity measurements (e.g. Tsokas and Hansen 1997, Tirel et al., 2004; Snopek, 2005) and travel time analysis from local and regional earthquakes (e.g. McKenzie 1972, 1978, Le Pichon and Angelier 1979, Jackson and McKenzie 1988, Spakman et al. 1988, Taymaz et al. 1996). Accurate geodetic data from triangulation and GPS measurements (e.g. Oral et al. 1995,

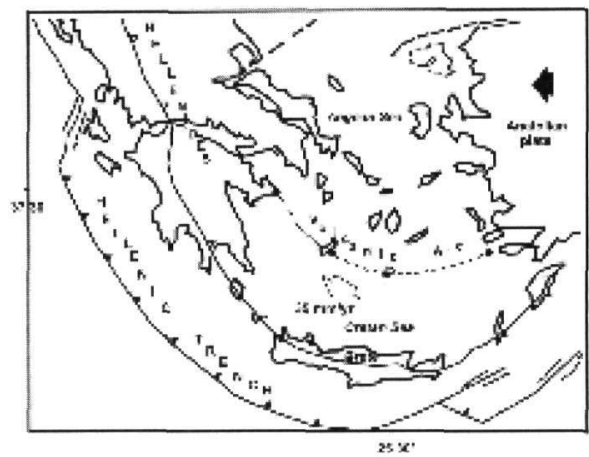

Figure 1 - Main tectonic structures of the Hellenic Arc and Trench system

Reilinger 1997, Kahle et al. 1998,; Papazachos 1999, McClusky et al. 2000) and geologic field observations provided important information on the regional active tectonics. Papazachos et al. (2000) identified from seismological observations a well-shaped Benioff zone to a depth up to 180 $\mathrm{km}$ below central Aegean, which starts at a depth of $20 \mathrm{~km}$ under the convex side of the sedimentary part of the arc and dips towards the back-arc area, with a dip angle about $30^{\circ}$ for shallow depths $(20 \mathrm{~km}<\mathrm{h}<100 \mathrm{~km})$ and of about $45^{\circ}$ for greater depths $(100 \mathrm{~km}<\mathrm{h}<180 \mathrm{~km})$.

In the present study we use the arrival times of P-waves of local earthquakes recorded at the stations of a new digital telemetry network operating on the island of Crete and other three regional networks in order to obtain the crustal structure of south Aegean. At the current stage of this work, we have focused on using well-constrained earthquake locations to produce velocity 
models and, by this way to relocate the whole available data set. The results from the above analysis will be furthermore used in order to relocate the earthquakes recorded in the last several decades in the area.

\section{Previous work on the determination of crustal structure of the Aegean}

\subsection{Introduction}

A better knowledge of the crustal structure in a region as complex as the Aegean is important to better understand its past and present tectonic and geodynamic evolution, as well as to improve the accuracy of local and regional earthquakes location. The crustal structure and thickness of the Aegean has been extensively investigated by a variety of studies using deep seismic soundings (e.g. Makris 1978, Makris and Stobbe 1984, Bohnhoff et al. 2001), gravity data (e.g. Tsokas and Hansen 1997, Tirel et al. 2004, Snopek 2005), surface wave data (e.g. Papazachos 1967, Karagianni et al. 2002) and receiver function inversion (Sodoudi et al. 2005). The mantle structure has been studied mostly by P-wave travel time inversion using local and teleseismic events (Spakman et al. 1988, Papazachos et al. 1995, Papazachos and Nolet 1997). In the next paragraph we shortly review the most significant results regarding the crustal structure of the Aegean.

\subsection{Main results of Seismic surveys on the crustal structure of Aegean}

Five seismic lines along the Cretan and Libyan Seas (Bohnhoff et al. 2001, Makris and Brönner 2001, Brönner 2003, Meier et al. 2004) as well as results from Expanding Spread Profiles analysis in the western Mediterranean (de Voogd et al. 1992, Truffert et al. 1993, Fruehn et al. 2002, Jones et al. 2002) provided detailed information about the structure of the deep basins and crust below Crete and at the collision front between the Aegean microplate and the oceanic lithosphere of the African plate. Additionally, the 20 reflection profiles which were shot along a $50 \mathrm{~km}$-wide corridor across the western Mediterranean Ridge in the framework of the International Mediterranean Ridge Seismic Experiment, IMERSE (Fruehn et al. 2002) and the Seismic study of the Mediterranean tectono-sedimentary prism, PRISMED surveys (Chaumillon and Mascle 1997, Huguen et al. 2001) provided information about the sedimentary structure of the Mediterranean Ridge.

More specifically, the results from the above deep seismic studies can be summarised in the following: Below the north part of central Crete the maximum thickness of the continental crust is estimated and found equal to $32.5 \mathrm{~km}$, whereas at the eastern part the crust is thinner ( 24 to $26 \mathrm{~km}$ ). In the upper crust P-wave velocity varies from 5.8 to $6.3 \mathrm{~km} / \mathrm{s}$ whereas at the lower crust from 6.4 to $6.9 \mathrm{~km} / \mathrm{s}$. Below central Cretan Sea the crust is thinner (about $15 \mathrm{~km}$ ) with maximum sediments thickness around $3.5 \mathrm{~km}$ and its maximum P-wave velocity equals to $4.35 \mathrm{~km} / \mathrm{s}$. Onshore central Crete the thickness of sediments is found to be up to $6 \mathrm{~km}$ consisting mainly of Mesozoic limestones (P-wave velocity 5.8 to $6.0 \mathrm{~km} / \mathrm{s}$ ) (Bohnhoff et al. 2001). To the south offshore the continental crust thins gradually to $17 \mathrm{~km}$ and extends about $100 \mathrm{~km}$ from the south of central Crete, $140 \mathrm{~km}$ south-west of the island and about $60 \mathrm{~km}$ south-east from the eastern coast. To the south it comes to contact with the thick sediments of the Mediterranean Ridge, which is in good agreement with the results from the IMERSE and PRISMED experiments. The southern border of the Aegean plate is located close to the border between the inner and the central units of the Mediterranean Ridge (e.g. Mascle et al. 1999, Huguen et al. 2001) about 100 to $120 \mathrm{~km}$ south of Crete.

Along the onshore southern profile, the crust is continental with a thickness of about $28 \mathrm{~km}$ at the central south Crete and $17 \mathrm{~km}$ of its southeast part. The point from decoupling of the dipping slab from the continental crust is located below SE Crete. The upper mantle velocities vary from 7.7 $\mathrm{km} / \mathrm{s}$ to $8.0 \mathrm{~km} / \mathrm{s}$ in the Aegean and African lithospheres, respectively. 
Receiver function (e.g. Knapmeyer and Harjes 2000, Li et al. 2003, Endrun et al. 2002) and surface wave studies (Meier et al. 2004) reveal an average depth of the oceanic Moho within the NE-dipping subducting African lithosphere about $55 \mathrm{~km}$ below Crete. The discontinuities found at about 30 to $35 \mathrm{~km}$ depth below central Crete are interpreted as Aegean continental Moho. Consequently, an about 10 to $15 \mathrm{~km}$ thick Aegean mantle wedge is assumed to be present beneath central Crete.

Table 1 - Moho depths from various studies (modified after Sodoudi 2005)

\begin{tabular}{|c|c|c|c|c|}
\hline Author(s ) & Methodology & Crete & $\begin{array}{c}\text { Cretan } \\
\text { Sea } \\
\text { minimum }\end{array}$ & Cyclades \\
\hline Papazachos (1967) & $\begin{array}{c}\text { seismic wave } \\
\text { velocity }\end{array}$ & - & - & $22-35$ \\
\hline Makris $(1975,1976,1977,1978)$ & $\begin{array}{l}\text { deep seismic } \\
\text { soundings and } \\
\text { Gravimetry }\end{array}$ & $30-32$ & 20 & 28 \\
\hline Makris and Vees (1977) & refraction & $30-32$ & 20 & 26 \\
\hline Calcagnile (1982) & $\begin{array}{c}\text { surface wave } \\
\text { dispersion }\end{array}$ & - & 35 & - \\
\hline Panagiotopoulos et al. (1985) & $\begin{array}{l}\text { Earthquake } \\
\text { Seismology }\end{array}$ & - & $24-30$ & - \\
\hline Papazachos et al. (1995) & $\begin{array}{c}\text { Seismic } \\
\text { tomography }\end{array}$ & $30-40$ & 25 & $25-30$ \\
\hline Tsokas and Hansen (1997) & Gravity & $28-30$ & 26 & $19-32$ \\
\hline Bohnhoff et al. (2001) & reflection/refraction & $24-32.5$ & 15 & - \\
\hline Vigner (2002) & Reflection & - & - & $26-25$ \\
\hline Karagianni et al. (2002) & $\begin{array}{c}\text { surface wave } \\
\text { dispersion }\end{array}$ & - & $22-24$ & - \\
\hline van der Meijde et al.(2002) & receiver function & - & 29 & 25 \\
\hline Li et al. (2003) & receiver function & $31-39$ & - & 25 \\
\hline Tirel et al. (2004) & Gravity & $28-31$ & 23 & 25 \\
\hline Karagianni et al. (2005) & $\begin{array}{l}\text { surface wave } \\
\text { tomography }\end{array}$ & - & $20-22$ & $24-26$ \\
\hline Sodoudi (2005) & $\begin{array}{c}\mathrm{P} \text { and } \mathrm{S} \text { receiver } \\
\text { functions }\end{array}$ & $28-32$ & $22-24$ & $24-30$ \\
\hline Snopek (2005) & gravity & $30-35$ & $15-25$ & $25-30$ \\
\hline
\end{tabular}

Tirel et al. (2004) created a new map for the Aegean crustal thickness inferred from inversion of marine gravimetric measurements. They observed a thin crust of about $22 \mathrm{~km}$ in the Cretan Sea, whereas the Cyclades are marked with a rather flat Moho of about $25 \mathrm{~km}$. Other scientists (e.g. Makris and Vees (1997), Li et al. (2003) estimate a depth of about 25-26 km of Moho beneath Cyclades, whereas they propose a rather thinner crust of about 15-20 km below the Cretan Sea.

Makris and Yegorova (2005) combining the results of Bohnhoff et al. (2001) and Brönner (2003) and by inverting gravity measurements concluded that the crust below central Crete is thick (32-34 $\mathrm{km})$ and at the eastern part is thinner $(24-26 \mathrm{~km})$. The Aegean crust south of Crete is covered by sediments having a thickness of 6 to $7 \mathrm{~km}$, and then $10 \mathrm{~km}$ of continental crust follows plus $6.5 \mathrm{~km}$ of subducted oceanic crust. Below western Crete the $21-25 \mathrm{~km}$ continental crust is followed by 6.5 $\mathrm{km}$ of oceanic crust resulting in a Moho depth at 30-32 km as previously defined by Makris (1977), Makris and Vees (1977), Tsokas and Hansen (1997), and Bohnhoff et al. (2001). 
Sodoudi (2005) applied the P and S receiver function analysis observed beneath the southern Aegean Basin to conclude a very thin crust, reaching $26 \mathrm{~km}$ eastwards, and a thicker crust at the Cyclades region, and to estimate the Moho depth at about $25-30 \mathrm{~km}$. In Table 1 the results concerning the Moho depths from the aforementioned studies, are summarized.

\section{Present work on the crustal structure of south Aegean}

\subsection{Description of the SASN network}

Accurate earthquake locations are an imperative prerequisite in order to seek for active structures in a study area and to investigate their geometric and kinematic properties. To this end a major requirement is the installation and operation of a local seismological network to provide optimum station coverage of the study area. Aiming to explore this information from the seismicity occurring along the Hellenic Arc, the data recorded at the digital telemetry network of the Geophysical \& Seismological Laboratory (GSL) of the Technological Educational Institute of Crete were used. The South Aegean Seismological Network (SASN) consists of nine short-period three-component seismic stations along the island of Crete, and one broadband station located in the city of Chania (Fig. 2). Network installation started in spring of 2004 and it was in full operation (10 stations) at the end of the same year. Recently this network expanded to the east with the installation of three new stations (SIT, IER and KLD). Table 2 provides information on station characteristics, as their names, geographical coordinates, altitude and type of seismometers. Additionally to these data all the available waveforms from the seismological stations at south Aegean operated by the GEOFON network (their sites are shown on Fig. 2) were analysed (http://www.gfz-potsdam.de/geofon/www_req/gfn_data.html). Moreover, the time arrivals from those earthquakes recorded also at the seismological stations of the National Observatory of Athens and the Seismological Network of Geophysics Department, Aristotle University of Thessaloniki were used in the present study.

Table 2 - Information on the stations characteristics

\begin{tabular}{|c|c|c|c|c|c|c|}
\hline $\begin{array}{c}\text { STATION } \\
\text { LOCATION }\end{array}$ & $\begin{array}{l}\text { CODE } \\
\text { NAME } \\
\end{array}$ & $\begin{array}{c}\text { LAT } \\
{ }^{\mathbf{0}} \mathbf{N}\end{array}$ & $\begin{array}{c}\text { LONG } \\
{ }^{\circ} \mathbf{E} \\
\end{array}$ & $\begin{array}{c}\text { ALT. } \\
(\mathbf{m})\end{array}$ & DAS & SEISMOMETER \\
\hline Chania (BB) & $\mathrm{CHNb}$ & 35.519 & 24.042 & 34 & & Guralp CMG-40T \\
\hline Chania & $\mathrm{CHN}$ & 35.519 & 24.042 & 76 & \multirow{12}{*}{$\begin{array}{c}\text { Reftek } \\
130 \mathrm{~A}\end{array}$} & Sercel L-4-3D $1 \mathrm{~Hz}$ \\
\hline Palaiochora & PLC & 35.234 & 23.686 & 25 & & Sercel L-4-3D $1 \mathrm{~Hz}$ \\
\hline Rethymno & RTH & 35.365 & 24.502 & 51 & & Sercel L-4-3D $1 \mathrm{~Hz}$ \\
\hline Gramvousa & GRM & 35.620 & 23.605 & 133 & & Sercel L-4-3D $1 \mathrm{~Hz}$ \\
\hline Sfakia & SFK & 35.201 & 24.138 & 79 & & Guralp CMG-40T-1 \\
\hline Hrakleio & HRK & 35.304 & 25.071 & 70 & & Guralp CMG-40T-1 \\
\hline Ag. Barbara & AGB & 35.140 & 25.132 & 629 & & Guralp CMG-40T-1 \\
\hline Ag. Galini & $\mathrm{AGL}$ & 35.096 & 24.688 & 26 & & Guralp CMG-40T-1 \\
\hline Kantanos & KAN & 35.326 & 23.740 & 473 & & Guralp CMG-40T-1 \\
\hline Kaloudiana & KLD & 35.487 & 23.690 & 100 & & Sercel L-4-3D 1Hz \\
\hline Sitia & SIT & 35.209 & 26.106 & 10 & & Guralp CMG-40T-1 \\
\hline Ierapetra & IER & 35.014 & 25.733 & 33 & & Guralp CMG-40T-1 \\
\hline
\end{tabular}

\subsection{Data analysis}

After the phase picking using the PQL program a preliminary location of the earthquakes was made. The velocity structure is very crucial since it provides the basis for the determination of the ray paths and hence the travel times. For the initial location, we considered the velocity structure proposed by Papazachos and Nolet (1997) and then we explore how it can be estimated in different regions from the travel times of P-waves. More than 1500 earthquakes were recorded by the stations used and located preliminary using the HYPOINVERSE (Klein 2000) computer program. 


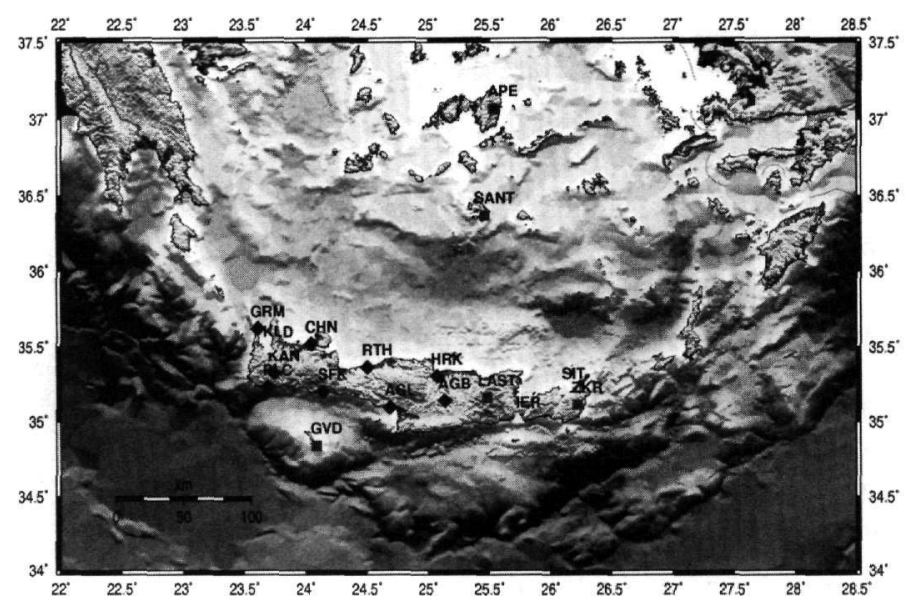

Figure 2 - Sites of the stations of SASN (diamonds represent the station sites during the time period of the present study, whereas the stations installed lately are represented by triangles) and GEOFON (squares), seismological networks

Having in mind that the use and interpretation of earthquake data especially for seismotectonic purposes strongly depend on accurate earthquake locations we are trying to select from the initial data set the earthquakes whose hypocentral parameters are well-determined. To achieve this goal we define some selection criteria adequate enough to allow us to end up with a set of adequately constrained earthquake locations. According to these, we include in our data set the earthquakes recorded by at least 7 stations (the minimum number of phases is fixed to 8, which means at least seven $\mathrm{P}$ and one $\mathrm{S}$ arrival time) with small time residuals. It has been shown in the literature, from experiments conducted in the same area (e.g. Hatzfeld et al. 1989), that earthquake locations with significant number of phase arrivals with small time residuals do not differ much if various reasonable velocity structures are adopted during the location process, and consequently they can be considered reliable. We set the error at the origin time (RMS) to be less than $0.5 \mathrm{~s}$, and the errors at the determination of the hypocenter (ERH) less than $5 \mathrm{~km}$ and (ERZ) less than $10 \mathrm{~km}$. Although the values of these errors have only statistical meaning, it has been shown in seismic sequences studies that aftershocks with similar error estimates represent satisfactorily the geometry of the fault, which caused the main shock (e.g. Karakostas et al. 2003). Applying these criteria we ended up with a set of 420 well constrained earthquake locations.

Aiming to improve the initial locations derived using a laterally homogeneous model we tried to develop velocity models for smaller regions and calculate residuals at individual stations, treating them later as station corrections. By this way we can avoid errors due to the different ray paths and different epicentral distances if the model and time residuals have been determined for large areas. Taking into account the spatial distribution of the epicenters and the specific tectonic features, we divided our study area into 15 smaller sub-regions, having in mind to keep a satisfactory number of well-located earthquakes in each one of them. After several trials and mapping of seismicity we ended up in the separation depicted in Figure 3. In an effort to determine the velocity structure of the area, i.e. evaluate the P-wave velocity as a function of depth, we constructed the travel time curves i.e. the travel times of P-waves versus the epicentral distance in each sub-region. With the appropriate algorithms based on the theory of refraction we calculated the velocity of P-waves and the thickness of each layer. The models derived after applying the aforementioned method consist of two or three layers over a half space. The value of the S-waves velocity is calculated indirectly through the value of the $V_{\mathrm{P}} / \mathrm{V}_{\mathrm{S}}$ ratio, a crucial parameter for the depth control of the earthquakes. We selected those events with more than five reliable $\mathrm{S}$ arrivals and we constructed individual Wadati plots. From the slope of the $\tau_{\mathrm{S}}-\tau_{\mathrm{P}}=\mathrm{f}\left(\tau_{\mathrm{P}}\right)$ curve we calculated a mean $V_{\mathrm{P}} / \mathrm{V}_{\mathrm{S}}$ ratio equal to 
$1.78 \pm 0.01$. This value was used later at the location process and it is in agreement with the results from other studies [e.g. 1.79 obtained by Hatzfeld et al. (1990), 1.80 by De Chabalier et al. (1992)].

For each sub-region separately we located the selected events using the new velocity model and examined the travel time residuals. In some cases, we obtained satisfactory results, whereas in others we had to try different values either in velocity or the thickness of a layer in order to achieve minimization of the mean RMS. These velocity models were further used to relocate all the recorded events using the HYPOINVERSE algorithm and calculate the stations delays.

Moreover, continuing the procedure of the relocation, time delays were determined and used as time corrections applying the following procedure. We relocated each event several times using the stations delays

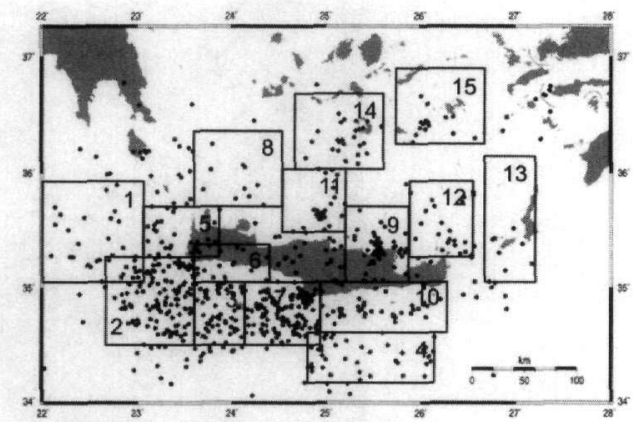

Figure 3 - Earthquakes used to define velocity models in 15 sub-regions shown on the map calculated at every iteration, eliminating at the same time the arrivals with large residuals. This iterative process comes to an end when there is no significant change at the earthquake location, which means that the mean time residual is less than $0.1 \mathrm{~s}$. For the present study the final mean time residual in all cases was less than $0.03 \mathrm{~s}$. The calculation of station delays is of great importance, since they contain the information about the lateral velocity variation. Groups of positive, negative or mixed station delays observed in different regions bear information about the crustal structure: positive station delays are mainly indicative of thick or/and slow crust compared to the assumed model and negative station delays are indicative of a thin or/and fast crust compared to the assumed model. The incorporation of station delays in the location process has resulted in a construction of a 3D velocity model from the 1D model, since the horizontal heterogeneities are taken into account. In Figure 4 the finally adopted velocity models determined for each sub-region are presented.

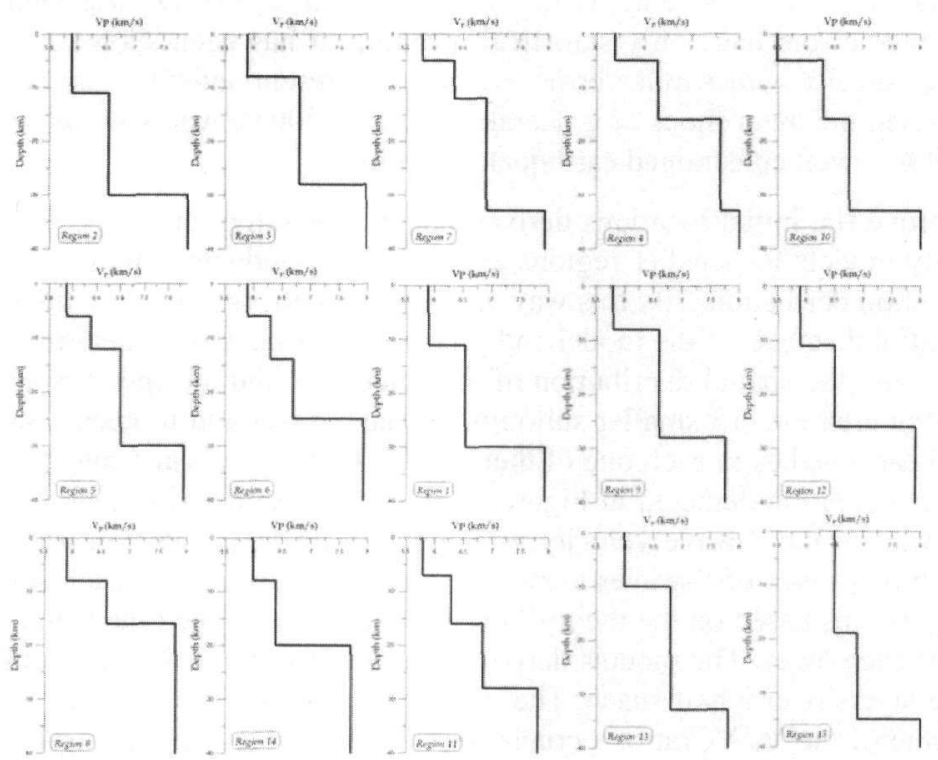

Figure 4-1D velocity models for each sub-region 
In regions 2,3,7,4 and 10 located south of Crete, we determined a crustal thickness of about 30-33 $\mathrm{km}$ and the P-waves velocity varying from 6.30 to $6.90 \mathrm{~km} / \mathrm{s}$. We observe a thin crust of about 17 $20 \mathrm{~km}$ in the central Cretan Sea (regions 8 and 14), with P-waves velocity $6.40-6.60 \mathrm{~km} / \mathrm{s}$, whereas in region 11 the thickness of the crust reaches the $27 \mathrm{~km}$. In western Crete (regions 5, 6), we observe that the thickness of the crust varies from $25-30 \mathrm{~km}$, and at the eastern part of the island (regions 9 and 12) the crust is thinner, 26-28 km. Finally, in regions 13 and 15 we observe a thick crust of about $33 \mathrm{~km}$.

\section{Results and Discussion}

Velocity models for the southern part of the Hellenic Arc have been determined using data from a local telemetry network on the island of Crete and three permanent regional networks, based on the travel time curves of reliably located earthquakes. In addition to these models time delays at all stations from events at different regions were calculated and applied as time corrections to improve the reliability of earthquake location in the area. Our final models are consistent with previous results concerning the crustal structure in the south Aegean. The back-arc area is generally characterized by a thin crust, while a thicker crust is observed under the accretionary prism. Based on these models and the calculated time delays we are working on the compilation of a new catalogue of seismic events with well-constrained hypocentral parameters. Further work will be done using all the available phase arrivals from the International Seismological Centre Bulletin, as well as from other local or regional experiments conducted at the area, in an effort to examine in more detail the geometry of the Benioff zone in the Hellenic arc, as well as the properties of the seismogenic layer, which overthrusts the Mediterranean lithosphere.

\section{Acknowledgments}

The GMT system (Wessel and Smith 1998) was used to plot the figures. Usage of data from GFZ Potsdam is also acknowledged. This work was supported by the project "Pythagoras" funded by the EPEAEK. Geophysics Department contribution 689.

\section{References}

Armijo, R., Meyer, B., King, G., Rigo, A., and Papanastasiou, D., 1996. Quaternary evolution of the Corinth Rift and its implications for the late Cenozoic evolution of the Aegean, Geophys. J. Int., 126, 11-53.

Bohnhoff, M., Makris, J., Papanikolaou, D., and Stavrakakis, G., 2001. Crustal investigation of the Hellenic subduction zone using wide aperture seismic data, Tectonophysics, 343, 239262.

Bohnhoff, M., Harjes, H.-P., and Meier, T., 2005. Deformation and stress regimes in the Hellenic subduction zone from focal mechanisms, Journal of Seismology, 9, 341-366.

Brönner, M., 2003. Untersuchung des Krustenaufbaus entlang des Mediterranen Rückens abgeleitet aus geophysikalischen Messungen, Ph.D. Dissertation, Universität Hamburg, 170pp.

Calcagnile, G., D'Ingeo, F., Farrugia, P., and Panza, G., 1982. The lithosphere in the CentralEastern Mediterranean area, Pure Appl. Geophys., 120, 389-406.

Chaumillon, E., and Mascle, J., 1997. From foreland to forearc domains: new multichannel seismic reflection survey of the Mediterranean ridge accretionary complex (Eastern Mediterranean), Mar. Geol., 138, 237-259.

De Chabalier, J., Lyon-Caen, H., Zollo, A., Deschamps, A., Bernard, P., and Hatzfeld, D., 1992. A detailed analysis of microearthquakes in western Crete from digital three-component seismograms, Geophys. J. Int., 110, 347-360. 
De Jonge, M. R., Wortel, M. J. R., and Spakman, W., 1994. Regional scale tectonic evolution and the seismic velocity structure of the lithosphere and upper mantle: The Mediterranean region, J. Geophys. Res., 99, 12091-12108.

De Voogd, B., Truffert, C., Chamot-Rooke, N., Huchon, P., Lallemant, S., and Le Pichon, X., 1992. Two-ship seismic soundings in the basins of the Eastern Mediterranean Sea (Pasiphae Cruise), Geophys. J. Int., 109, 536-552.

Endrun, B., Meier, T., Bischoff, M., and Harjes, H.P., 2004. Lithospheric structure in the area of Crete constrained by receiver functions and dispersion analysis of Rayleigh phase velocities, Geophys. J. Int., 158, 592-608.

Fruehn, J., Reston, T., von Huene, R., and Bialas, J., 2002. Structure of the Mediterranean Ridge accretionary complex from seismic velocity information, Mar. Geol., 186, 43-58.

Geofon Data Center, http://www.gfz-potsdam.de/geofon/www_req/gfn_data.html.

Hatzfeld, D., Pedotti, G., Hatzidimitriou, P., Panagiotopoulos, D., Scordilis, M., Drakopoulos, I., Makropoulos, K., Delibasis, N., Latousakis, I., Baskoutas, J., and Frogneux, J., 1989. The Hellenic subduction beneath the Peloponnesus: first results of a microearthquake study, Earth and Plan. Science Letters, 93, 283-291.

Hatzfeld, D., Pedotti, G., Hatzidimitriou, P., and Makropoulos, K., 1990. The strain pattern in the western Hellenic arc deduced from a microearthquake survey, Geophys. J. Int., 101, 181202.

Huguen, C., Mascle, J., Chaumillion, E., Woodside, J., Benkhelil, J., Kopf, A., and Volkonskaya, A., 2001. Deformation styles of the eastern Mediterranean Ridge and surroundings from combined swath mapping and seismic reflection profiling, Tectonophysics, 343, 21-47.

International Seismological Centre, 2001. On-line Bulletin, http://www.isc.ac.uk/_Bull, Internat. Seis. Cent., Thatcham, United Kingdom.

Jackson, J., and McKenzie, D., 1988. The relationship between plate motions and seismic moment tensors and the rates of active deformation in the Mediterranean and Middle East, Geophys. $J ., 93,45-73$.

Jackson, J., 1994. Active tectonics of the Aegean region, Annu. Rev. Earth Planet. Sci., 22, 239271.

Jones, K., Warner, W., Le Meur, D., Pascal, G., Tay, P., and the IMERSE Working Group, 2002. Wide-angle images of the Mediterranean Ridge backstop structure, Mar. Geol., 186, 145166.

Kahle, H., Straub, D., Reilinger, R., McClusky, S., King, R., Hurst, K., Veis, G., Kastens, K., and Cross, P., 1998. The strain rate field in the eastern Mediterranean region, estimated by repeated GPS measurements, Tectonophysics, 294, 237-252.

Karagianni, E., Panagiotopoulos, D., Panza, G., Suhadolc, P., Papazachos, C., Papazachos, B., Kiratzi, A., Hatzfeld, D., Makropoulos, K., Priestley K., and Vuan, A., 2002. Rayleigh wave group velocity tomography in the Aegean area, Tectonophysics, 358, 187-209.

Karagianni, E., Papazachos, C., Panagiotopoulos, D., Suhadolc, P., Vuan, A., and Panza, G., 2005. Shear velocity structure in the Aegean area obtained by inversion of Rayleigh waves, Geophys. J. Int., 160, 127-143.

Karakostas, V., Papadimitriou, E., Karakaisis, G., Papazachos, C., Scordilis, M., Vargemezis, G., and Aidona, E., 2003. The 2001 Skyros, Northern Aegean, Greece, earthquake sequence: off - fault aftershocks, tectonic implications, and seismicity triggering, Geophys. Res. Letters, 30, (1), 1012, doi:10.1029/2002GL015814. 
Klein, F., 2002. User's Guide to HYPOINVERSE-2000, a Fortan program to solve for earthquakes locations and magnitudes, Open file report 02-171, USGS.

Knapmeyer, M., and Harjes, H.-P., 2000. Imaging crustal discontinuities and the downgoing slab beneath western Crete, Geophys. J. Int., 143, 1-21.

Le Pichon, X., and Angelier, J., 1979. The Aegean arc and trench system: a key to the neotectonic evolution of the eastern Mediterranean area, Tectonophysics, 60, 1-42.

Li, X., Bock, G.,Vafidis, A., Kind, R., Harjes, H.-P, Hanka, W.,Wylegalla, K., van der Meijde, M., and Yuan, X., 2003. Receiver function study of the Hellenic subduction zone: imaging crustal thickness variations and the oceanic Moho of the descending African lithosphere, Geophys. J. Int., 155, 733- 748

Makris, J., 1975. Crustal structure of the Aegean Sea and the Hellenides obtained from geophysical surveys, J. Geophys., 41, 441-443.

Makris, J., 1976. A dynamic model of the Hellenic arc deduced from geophysical data, Tectonophysics, 36, 339-346.

Makris, J., 1977. Geophysical investigation of the Hellenides, Geo. Einz. Hamburger 34, 124pp.

Makris, J., and Vees, R., 1977. Crustal structure of the Central Aegean Sea and the islands of Evia and Crete, Greece, obtained by refractional seismic experiments, J. Geophys., 42, 329- 341 .

Makris J., 1978. The crust and upper mantle of the Aegean region from deep seismic soundings, Tectonophysics, 6, 269- 284.

Makris, J., and Stobbe, C., 1984. Physical properties and state of the crust and upper mantle of the eastern Mediterranean Sea deduced from geophysical data, Ma. Geol., 55, 347-363.

Makris, J., and Brönner, M., 2001. Crustal shortening along the Cretan Arc obtained by active seismic experiments, CIESM Congress Proceedings vol. 36, Monte-Carlo, Monako.

Makris, J., and Yegorova, T., 2005. A 3-D density-velocity model between the Cretan Sea and Libya, Tectonophysics, 417, 201-220.

Mascle, J., Huguen, C., Benkhelil, J., Chamot-Rooke, N., Chaumillion, E., Foucher, J.P., Griboubard, R., Kopf, A., Lamarche, G., Volkonskaia, A., Woodsite, J., and Zitter, T., 1999. Images may show start of European-African collision. Eos, Transactions, $A G U, 80,421-428$.

McClusky, S., Balassanian, S., Barka, A., Demir, C., Ergintav, S., Georgiev, I., Gurkan, O., Hamburger, M., Hurst, K., Kahle, H., Kastens, K., Kekelizde, G., King, R., Kotzev, V., Lenk, O., Mahmoud, S., Mishin, A., Nadariya, M., Ouzounis, A., Paradissis, D., Peter, Y., Prilepin, M., Reileinger, R., Sanli, I., Seeger, H., Tealeb, A., Toksoz,, M., and Veis, G., 2000. Global Positioning System constraints on plate kinematics and dynamics in the Eastern Mediterranena and Caucasus, J. Geophys. Res., 105, 5695-5719.

McKenzie, D., 1972. Active tectonics of the Mediterranean region, Geoph. J. R. Astron. Soc., 30, 109-182.

McKenzie, D.P., 1978. Active tectonics of the Alpine-Himalayan belt: the Aegean Sea and surrounding regions, Geophys. J. Royal Astron. Soc., 55, 217-254.

Meier, T., Rische, M., Endrun, B., Vafidis, A., and Harjes, H.-P., 2004. Seismicity of the Hellenic subduction zone in the area of western and central Crete observed by temporary local seismic networks, Tectonophysics, 383, 149-169.

Mercier, J., Sorel, D., and Vergely, P., 1989. Extensional tectonics regimes in the Aegean basins during the Cenozoic, Basin Res., 2, 49-71. 
Oral, M., Reilinger, R., Toksoz, M., King, R., Barka, A., Kiniki, J., and Lenk, D., 1995. Global Positioning system offers evidence of plate motions in eastern Mediterranean, EOS, 76, 911.

Panagiotopulos, D., and Papazachos, B., 1985. Travel times of Pn waves in the Aegean and surrounding area, Geophys. J. R. Astron. Soc., 80, 165-176.

Papazachos, B., Polatou, M., and Mandalos, N., 1967. Dispersion of surface waves recorded in Athens, Pure Appl. Geophys., 67, 95-106.

Papazachos, B. C., and Comninakis, P. E., 1970. Geophysical features of the Greek island arc and eastern Mediterranean ridge, Com. Ren. Sceances Conf. Reunie a Madrid, 1969, 16, 74-75.

Papazachos, B., Kiratzi, A, and Papadimitriou, E., 1991. Regional focal mechanisms for earthquakes in the Aegean area, Pure Appl. Geophys., 136, 405-420.

Papazachos, C., 1994. Structure of the crust and upper mantle in SE Europe by inversion of seismic and gravimetric data ,PhD thesis, Univ. of Thessaloniki, Greece. (in Greek)

Papazachos, C., Hatzidimitriou, P., Panagiotopoulos, D., and Tsokas, G., 1995. Tomography of the crust and upper mantle in Southeast Europe, J. Geophys. Res., 100, 405-422.

Papazachos, C.B., and Kyratzi, A., 1996. A detailed study of the active deformation in the Aegean and surrounding area, Tectonophysics, 253, 129-153.

Papazachos, C., and Nolet, G., 1997. P and S deep velocity structure of the Hellenic area obtained by robust nonlinear inversion of traveltimes, J. Geophys. Res., 102, 8349-8367.

Papazachos, C., 1999. Seismological and GPS evidence for the Aegean-Anatolia interaction. Geophys. Res. Lett., 17, 2653-2656.

Papazachos, B., Karakostas, V., Papazachos, C., and Scordilis, E., 2000. The geometry of the Wadati-Benioff zone and lithospheric kinematics in the Hellenic arc, Tectonophysics, 319, 275-300.

Reilinger, R., McClusky, S., Oral, M., King, R., Toksoz, M., Barka, A., Kinik, I., Lenk, O., and Sanli, I., 1997. Global positioning system measurements of present-day crustal movementsin the Arabia-Africa-Eurasia plate collision zone, J. Geophys. Res., 102, 9983-9999.

Snopek, K., 2005. Inversion of gravity data with application to density modelling of the Hellenic subduction zone, PHD thesis, Ruhr-University Bochum.

Sodoudi, F., Kind, R., Hatzfeld, D., Hanka, W., Wylegalla, K., Vafidis, A., Stavrakakis, G., Priestley, K., and Harjes, H.-P., 2005. Lithospheric structure in the Aegean area and Greece obtainded from $\mathrm{P}$ and S receiver function methods, $2^{\text {nd }}$ Gen. Assembly Europ. Geosciences Union, Vienna, Austria 2005.

Sodoudi, F., 2005. Lithospheric structure of the Aegean obtained from P and S receiver functions, PHD thesis, Berlin Universität.

Spakman, W., Wortel, M., and Vlaar, N., 1988. The Aegean subduction zone: a tomographic image and its geodynamic implications, Geophys. Res. Lett., 15, 60-63.

Spakman, W., van der Lee, S., and van der Hilst, R., 1993. Travel-time tomography of the European Mediterranean mantle down to 1400 km, Phys. Earth Plant. Inter., 79, 3-74.

Taymaz, T., Jackson, J., and Westaway, R., 1990. Earthquake mechanisms in the Aegean trench near Crete, Geophys. J. Inter, 102, 695-731.

Taymaz, T., 1996. S-P-wave travel-time residuals from earthquakes and lateral inhomogeneity in the upper mantle beneath the Aegean and the Aegean Trench near Crete, Geophys. J. Int., 
$127,545-558$.

Tirel, C., Gueydan, F., Tiberi, C., and Brun, J.P., 2004. Aegean crustal thickness inferred from gravity inversion. Geodynamical implications, Earth and Plan. Science Letters, 228, 267280.

Truffert, C., Chamot-Rooke, N., Lallemant, S., De Voogd, B., Huchon, P., and Le Pichon, X., 1993. The crust of the Western Mediterranean Ridge from deep seismic data and gravity modelling, Geophys. J. Int., 114, 360-372.

Tsokas, G., and Hansen, R., 1997. Study of the crustal thickness and the subducting lithosphere in Greece from gravity data, J. Geophys. Res., 102, 520585-520597.

van der Meijde, M., van der Lee, S., and Giardini, D., 2003. Crustal structure beneath broad-band seismic stations in the Mediterranean region, Geophys. J. Int., 152, 729-739.

Vigner, A., 2002. Images sismiques par reflexions verticales et grande angle de la croûte en contexte extensif: les Cyclades et le fossé Nord-Egéen, PHD thesis, Institut Physique du Globe de Paris, 269pp.

Wessel, P., and Smith, W.H.F., 1998. New, improved version of the Generic Mapping Tools Released, EOS Trans. AGU 79, 579pp.

Wortel, M.J.R, and Spakman, W., 1992. Structure and dynamics of subducted lithosphere in the Mediterranean region, Proc. K. Ned. Akad. Wet., 95, 325-347. 